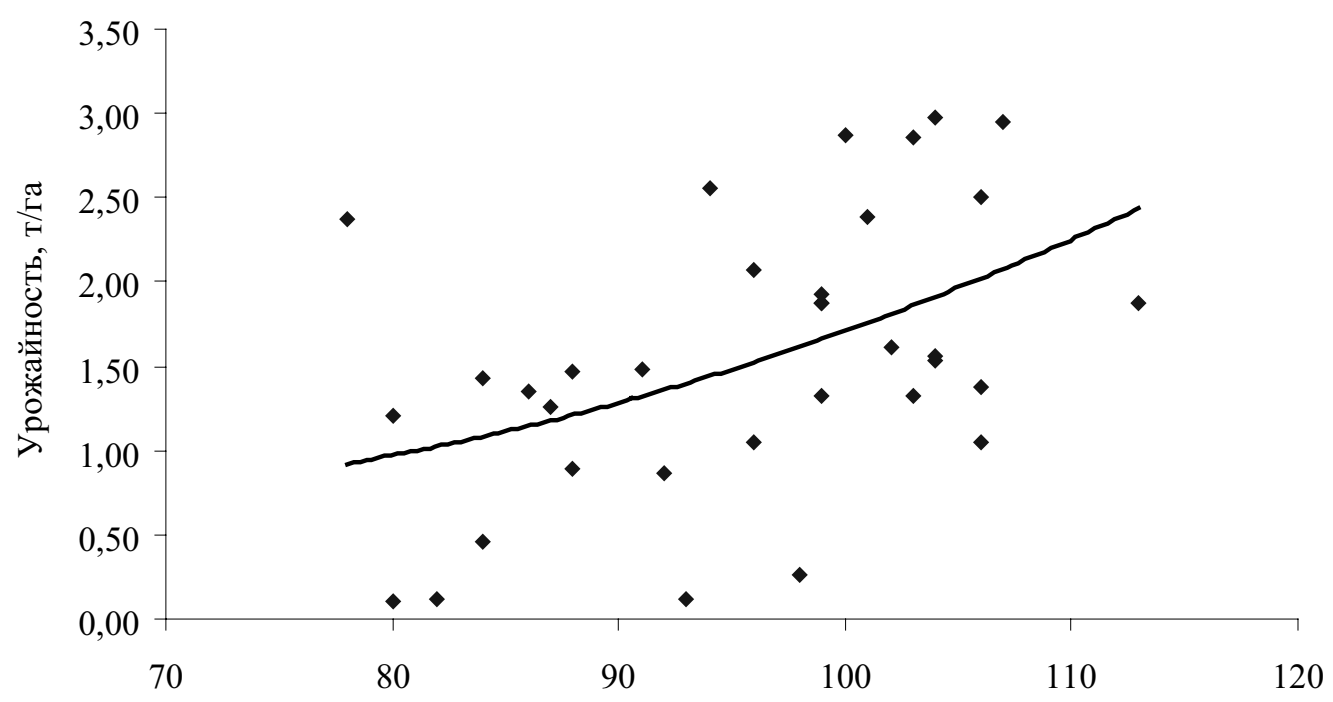

Продолжительность вегетационного периода, дни

Зависимость урожайности яровой пшеницы от продолжительности вегетационного периода

Проведенный анализ позволил выявить некоторые закономерности формирования продуктивности яровой пшеницы по отдельным межфазным периодам ее развития. Исследования в данном направлении способствуют более эффективному использованию природных ресурсов территории при возделывании яровой пшеницы. Полученные данные могут быть использованы как показатели контроля за состоянием растений и для принятия решений в процессе возделывания данной культуры.

УДК 911.3(470.44)

\section{СТРУКТУРНАЯ ХАРАКТЕРИСТИКА ГОРОДСКОГО НАСЕЛЕНИЯ САРАТОВСКОЙ ОБЛАСТИ (этнический аспект)}

\section{С.в Уставщикова}

Саратовский государственный университет, кафедра экономической географии

E-mail: Reena1@yandex.ru

В статье рассмотрены изменения в демографической структуре городского населения Саратовской области (в частности, населения больших городов) за период 1989-2006 гг. Дается социальноэкономическая характеристика населения по таким показателям, как образование, источники средств к существованию, положение в занятии, виды экономической деятельности. Анализ осуществляется по материалам Всероссийской переписи населения 2002 года. Рассматривается этнический аспект.

\section{Библиографический список}

1. Вавилов Н.И. Мировые ресурсы хлебных злаков. М., 1964. $123 \mathrm{c}$.

2. Константинов А.Р., Зоидзе Е.К., Смирнова С.И. Почвенно-климатические ресурсы и размещение зерновых культур. Л., 1981. 264 с.

3. Дегтярева Г.В. Погода, урожай и качество зерна яровой пшеницы. Л.,1981. $216 \mathrm{c}$.

4. Вериго С.А., Разумова Л.А. Почвенная влага. Л., 1973. $327 \mathrm{c}$.

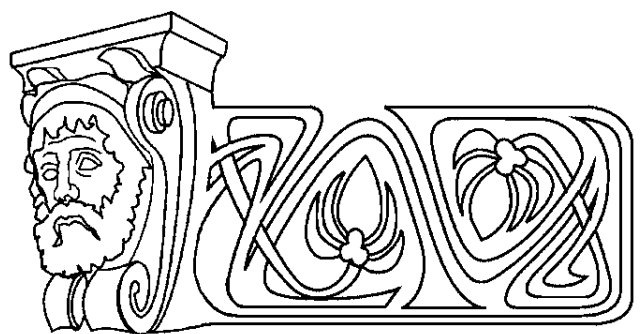

Structural Characterization of Saratov's Region Citizens (Ethnical Aspect)

\section{S.V. Ustavshchikova}

The changes in demographic structure of Saratov's region citizens (particularly the population of big cities) from 1989 to $2006 \mathrm{y}$. were examined in the article. Socio-economic characterization of region's citizens was given by such indexes as: education, paycheque, work status and kinds of economic activity. In the article census information (2002 y.) was used. Ethnical aspect was also examined. 
Процессы урбанизации в Саратовской области на рубеже веков были схожи с основными тенденциями в Российской Федерации в целом. За период 1989-2002 гг. в стране наблюдалось:

- сокращение численности городского населения, рост сельского;

- «административная рурализация» - преобразование городских поселений - в сельские;

- рост числа городов.

В Саратовской области за период с 1989 по 2007 г. уменьшилось число городских поселений с 50 до 45. При этом число городов увеличилось с 17 до 18 (Шиханы получили статус города), а число поселков городского типа сократилось с 33 до 27, в том числе три районных центра области - р.п. Александров Гай, Ивантеевка, Питерка - стали сельскими поселениями. Численность населения, проживающего в поселках городского типа, сократилась на $11,4 \%$. В области 13 из 18 городов представлены малыми городами с числом жителей, не превышающим 50 тыс. человек (табл. 1).

Таблица 1

Численность городского населения [1,2]

\begin{tabular}{|l|c|c|c|c|}
\hline \multirow{2}{*}{ Год } & \multicolumn{4}{|c|}{ Городское население, тыс. чел. } \\
\cline { 2 - 5 } & Всего & $\begin{array}{c}\text { В том числе } \\
\text { в поселках городского типа }\end{array}$ & В городах & $\begin{array}{c}\text { В том числе } \\
\text { в больших городах* }\end{array}$ \\
\hline 1989 & 1990,1 & 238,4 & 1751,7 & 1378,8 \\
\hline 1989, в \% к итогу & 100,0 & $12,0 \%$ & 88,0 & 69,3 \\
\hline 2002 & 1963,9 & 211,4 & 1752,5 & 1365,9 \\
\hline 2002, в \% к итогу & 100,0 & 10,7 & 89,3 & 69,5 \\
\hline 2007 & 1917,7 & 203,4 & 1714,3 & 1334,7 \\
\hline 2007, в \% к итогу & 100,0 & 10,6 & 89,4 & 69,6 \\
\hline
\end{tabular}

* По классификации городов в Российской Федерации большими считаются города, с численностью населения 100 тыс. человек и более. Город Балашов с численностью населения 93,4 тыс. чел. в условиях Саратовской области можно отнести к категории больших.

Итак, несмотря на некоторые новые тенденции динамики городского и сельского населения, говорить о прекращении процесса урбанизации в Саратовской области, видимо, нет оснований. Доля горожан - после некоторого снижения в 1990-е гг. - стабилизировалась в 2000-2005 гг. на уровне 73,6\%, к 2007 г. выросла до 73,9\%. Удельный вес горожан, проживающих в городах, особенно в больших, постоянно возрастает.

Город - это его население. Качественную характеристику населения дают переписи. В публикациях материалов переписи 2002 г. по Саратовской области значительная доля каче- ственной характеристики населения дана в разрезе городского и сельского населения. Около $70 \%$ всех горожан области проживают в 4 больших городах: Саратове, Балаково, Балашове, Энгельсе. Поэтому можно с небольшим допущением принять, что качественные показатели городского населения по области в целом - это характеристика населения больших городов.

Численность населения больших городов области сокращалась в межпереписной период 1989-2002 гг. и продолжает сокращаться, исключение составляет г. Энгельс (табл. 2).

Таблица 2

Динамика численности населения больших городов Саратовской области $[1,2]$

\begin{tabular}{|l|c|c|c|c|}
\hline \multicolumn{1}{|c|}{ Город } & 1989 (тыс. чел.) & 2002 (тыс. чел.) & 2002 в \% к 1989 & 2007 (тыс.чел.) \\
\hline Саратов & 902,3 & 873,1 & 96,8 & 841,4 \\
\hline Балаково & 199,3 & 200,5 & 100,6 & 199,1 \\
\hline Балашов & 95,2 & 98,3 & 103,3 & 93,4 \\
\hline Энгельс & 181,9 & 193,9 & 106,6 & 200,8 \\
\hline
\end{tabular}

Изменение численности связано с показателями естественного и миграционного движения населения. Естественный прирост по городам отрицательный, это связано с превышением числа умерших над родившимися, что не в последнюю очередь связано с постарением населения. Oсобенно это характерно для г. Балашова (табл. 3).

Миграционные передвижения представляют собой массовые, в количественном отношении, и сложные, в структурном отношении, социально- демографические процессы. Саратовская область является одним из принимающих регионов России.

Большинство мигрантов стремятся закрепиться в городской местности, причем приоритетное положение занимают крупные многопрофильные города Балаково, Энгельс, где достаточно развита рыночная инфраструктура жилья, существует широкий рынок труда. Саратов и Балашов теряют население как в результате естественного, так и миграционного движения (табл. 4). 
Таблица 3

Рождаемость, смертность, естественный прирост (на 1000 жителей) [1,2]

\begin{tabular}{|l|c|c|c|c|c|c|}
\hline \multirow{2}{*}{ Город } & \multicolumn{2}{|c|}{ Рождаемость } & \multicolumn{2}{c|}{ Смертность } & \multicolumn{2}{c|}{ Естественный прирост } \\
\cline { 2 - 7 } & 1990 & 2006 & 1990 & 2006 & 1990 & 2006 \\
\hline Саратов & 11,7 & 8,5 & 11,6 & 15,2 & 0,1 & $-6,7$ \\
\hline Балаково & 14,4 & 8,4 & 8,6 & 13,5 & 5,8 & $-5,1$ \\
\hline Балашов & 10,8 & 7,1 & 12,7 & 16,3 & $-1,9$ & $-9,2$ \\
\hline Энгельс & 14,2 & 9,0 & 10,9 & 14,2 & 3,3 & $-5,2$ \\
\hline
\end{tabular}

Таблица 4

Миграционный прирост (убыль) населения по городам, чел. [2]

\begin{tabular}{|l|c|c|c|c|}
\hline \multicolumn{1}{|c|}{ Город } & 2003 & 2004 & 2005 & 2006 \\
\hline Саратов & 185 & 662 & -2031 & -3502 \\
\hline Балаково & 209 & 843 & 742 & 906 \\
\hline Балашов & 140 & 120 & -237 & -214 \\
\hline Энгельс & 13 & 1631 & 4539 & 7365 \\
\hline
\end{tabular}

Рассмотренные выше процессы - сокращение рождаемости, рост смертности, миграционные изменения в больших городах области - влияют на изменение возрастного состава населения (рис. 1).

Самое «старое» население (доля людей в возрасте старше трудоспособного) в Саратове и Балашове. Однако в Саратове чуть выше доля совсем молодых. Из районов Саратова Фрунзенский район самый «старый» по составу населения, Ленинский - самый молодой.
В Саратовской области проживают более 110 этносов. Этнический состав свидетельствует об этнических процессах, этнических различиях в естественном воспроизводстве и об этнических миграциях населения области. В табл. 5 показана динамика численности населения различных национальностей по городским поселениям. Самыми «городскими» являются евреи, русские, армяне, азербайджанцы, украинцы, татары (доля проживающих в городах из общей численности каждого народа более 65\%).

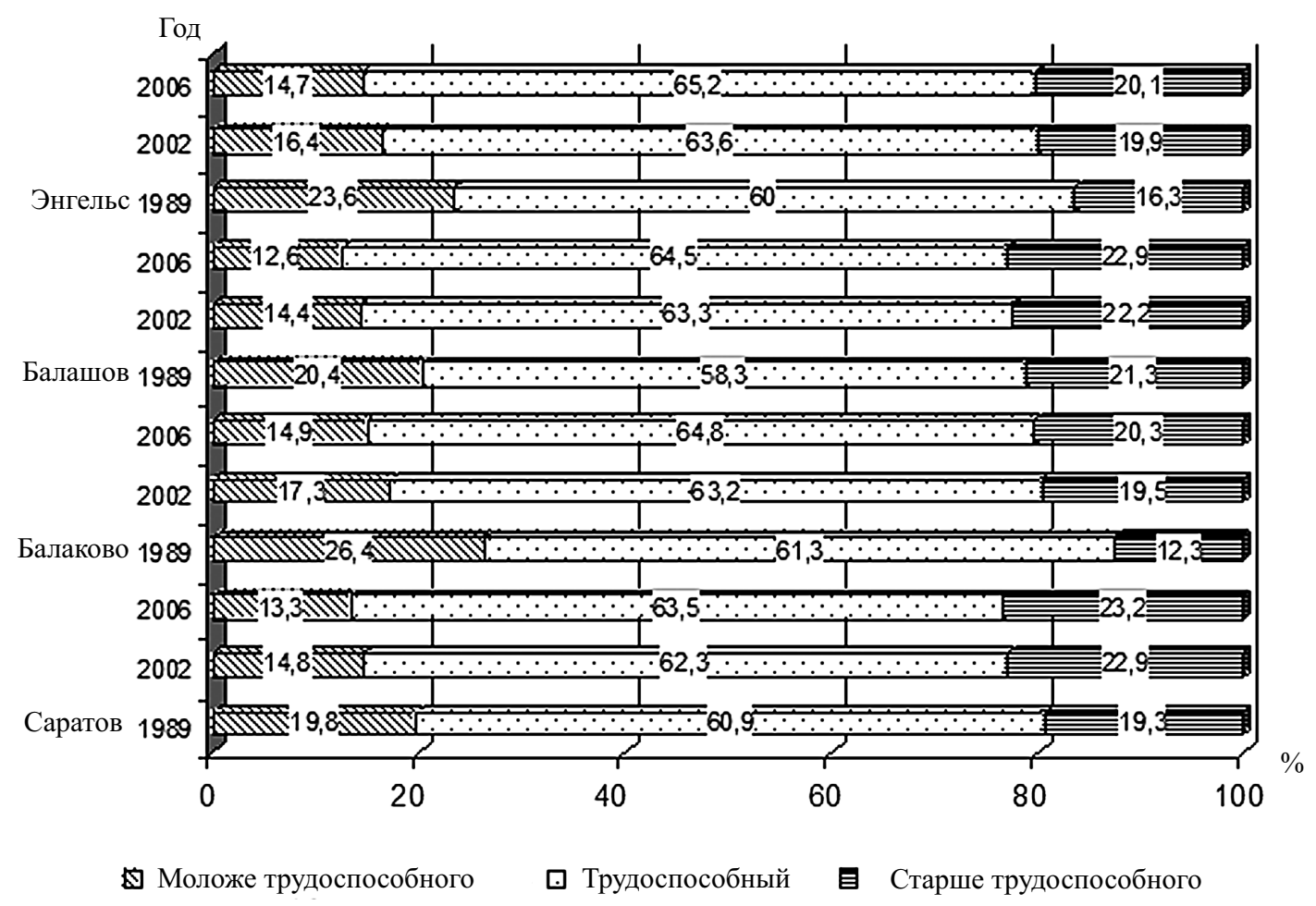

Рис.1. Распределение населения больших городов области по возрастным группам $[1,2]$ 
Изменение численности населения по национальностям (городское население), чел. [3]

\begin{tabular}{|l|c|c|c|c|c|c|c|}
\hline \multirow{2}{*}{ Народы } & \multirow{2}{*}{1979} & \multirow{2}{*}{1989} & \multirow{2}{*}{2002} & \multicolumn{3}{c|}{ В \% к итогу } & \multirow{2}{*}{$\begin{array}{c}\text { 2002 в \% от численно- } \\
\text { сти этноса в городе }\end{array}$} \\
\cline { 1 - 4 } & & & & 1979 & 1989 & 2002 & \multicolumn{2}{c|}{100} \\
\hline Все население & 1815464 & 1990129 & 1963858 & 100 & 100 & 100 & 76,8 \\
\hline Русские & 1637163 & 1777113 & 1761898 & 90,2 & 89,3 & 89,7 & 21,3 \\
\hline Казахи & 12537 & 19652 & 16716 & 0,7 & 1,0 & 0,9 & 67,2 \\
\hline Украинцы & 67932 & 71865 & 45231 & 3,7 & 3,7 & 2,3 & 65,7 \\
\hline Татары & 29454 & 34571 & 37815 & 1,6 & 1,7 & 1,9 & 72,6 \\
\hline Армяне & 3132 & 4702 & 18130 & 0,2 & 0,2 & 0,9 & 52,9 \\
\hline Мордва & 11395 & 13216 & 8745 & 0,6 & 0,7 & 0,5 & 67,5 \\
\hline Азербайджанцы & 2187 & 6142 & 11095 & 0,1 & 0,4 & 0,6 & 42,0 \\
\hline Чуваши & 6331 & 8686 & 6696 & 0,3 & 0,3 & 0,4 & 64,9 \\
\hline Белорусы & 10558 & 12267 & 8228 & 0,6 & 0,6 & 0,4 & 41,7 \\
\hline Немцы & 4067 & 6164 & 5039 & 0,2 & 0,3 & 0,3 & 41,4 \\
\hline Народы Дагестана & 1255 & 3828 & 4636 & 0,1 & 0,2 & 0,2 & 30,4 \\
\hline Чеченцы & 508 & 1229 & 2593 & 0,0 & 0,1 & 0,1 & 36,7 \\
\hline Башкиры & 1106 & 1653 & 1465 & 0,1 & 0,1 & 0,1 & 35,9 \\
\hline Марийцы & 1220 & 1786 & 1429 & 0,1 & 0,1 & 0,1 & 42,9 \\
\hline Молдаване & 1914 & 2166 & 1646 & 0,1 & 0,1 & 0,1 & 96,8 \\
\hline Евреи & 10129 & 7872 & 3319 & 0,6 & 0,4 & 0,2 & \\
\hline
\end{tabular}

Численность и доля в городском населении армян и азербайджанцев значительно возросли, мордвы, белорусов, евреев - сократилась, что связано как с процессами естественного и механического движения населения, так и с ассимиляционными.

В областном центре русские составляют $90 \%$ населения. В Саратове самые многочисленные после русских такие национальности, как украинцы (1,8\% от всего населения города), татары (1,7\% ), армяне (1\%), азербайджанцы $(0,7 \%)$. В Балашове доля русских в населении 95,4\%, украинцев $-1,8$. В Балаково русские составляют $91 \%$ населения, украинцы - 2,2, татары-1,7\%. В г. Энгельсе доля русских в населении - 88,5\%, украинцев - 3,4\%, татар $-2,7 \%$

Изменение в населении доли той или иной национальности в настоящем и будущем зависит и от сложившейся возрастной структуры. Анализ возрастной структуры разных народов позволяет сделать следующие выводы:

- поколенная ассимиляция деформирует возрастную структуру украинцев, мордвы, чувашей, белорусов, о чем свидетельствует неестественно низкая доля «молодых» у этих народов и очень высокий медианный возраст (у белорусов $-50,5$ лет, у мордвы - 49,5 года);

- заниженная доля «старших» среди армян, азербайджанцев, чеченцев - подтверждение изменения их численности в городах области в результате миграций;

- низкая доля «пожилых» у казахов в городском населении показывает тенденцию «моло- дежной урбанизированности» этого, все еще в основном «сельского» народа (рис. 2).

Качество населения определяется состоянием его здоровья, уровнем образования, профессиональной структурой. Уровень образования населения в настоящее время можно считать «пороговым» показателем, раскрывающим ориентацию человека на приобретение наиболее высокого социального статуса в обществе. На его получение в большей мере ориентированы русские, украинцы, белорусы, армяне, чеченцы.

По доли населения, имеющего высшее (в том числе послевузовское) и неполное высшее образование, среди больших городов на первом месте Саратов (330 чел. из 1000), затем Энгельс (240), Балашов (234) и Балаково (186 чел. на 1000) (рис. 3).

Население области различается по источникам средств к существованию (это одна из качественных характеристик населения, выявляющихся только в результате переписи). Значительная часть населения в настоящее время имеет несколько источников средств к существованию. В большинстве случаев это «доход от трудовой деятельности» и «пособия» или «пенсия» и «доход от трудовой деятельности». Так, из 145 млн россиян примерно 103 млн указали один источник средств к существованию, т. е. около $70 \%$, у остальных 42 млн их оказалось больше (в среднем чуть меньше двух) [4]. В Саратовской области $74,7 \%$ граждан указали только один источник средств к существованию. Этот показатель значительно выше среди населения трудоспособного и 


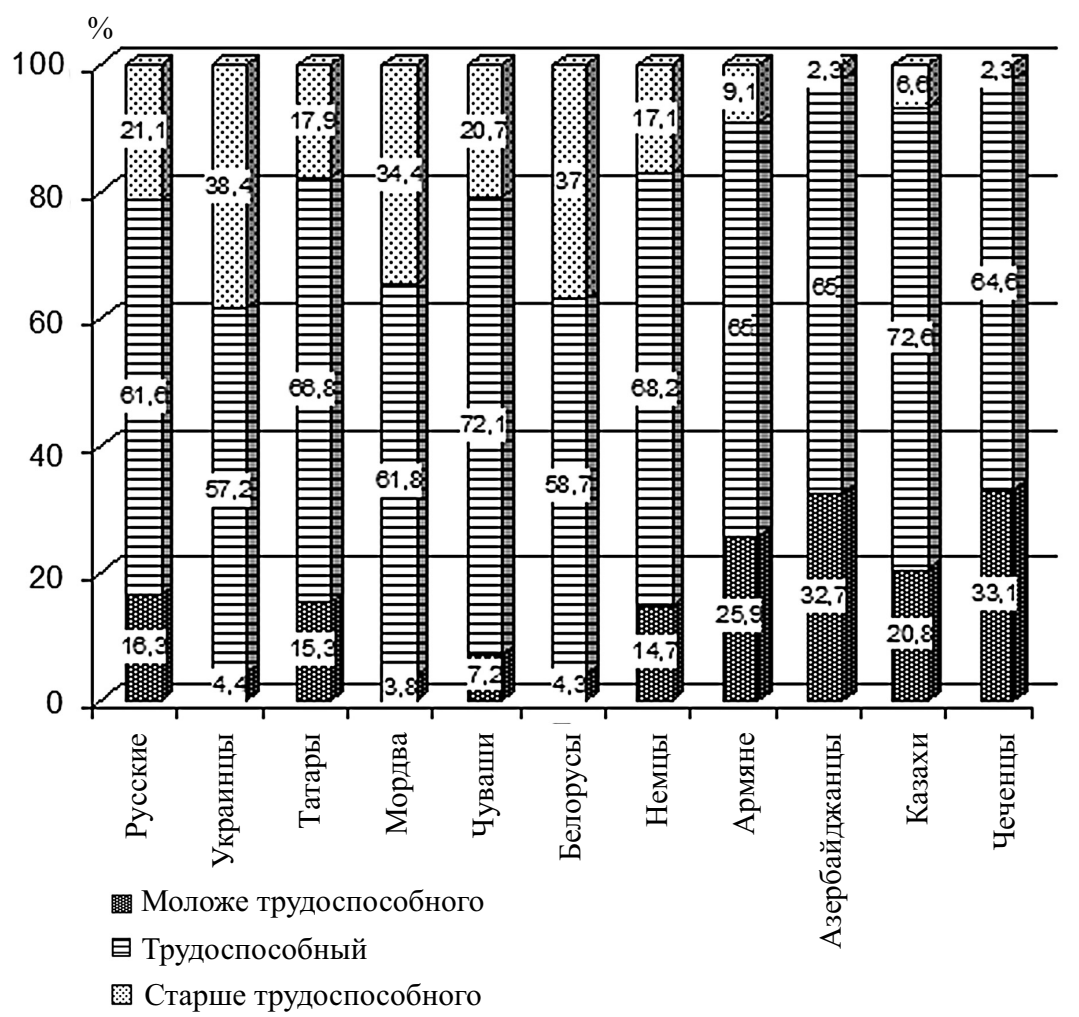

Рис.2. Возрастной состав городского населения, 2002 г. (этнический аспект) [3]

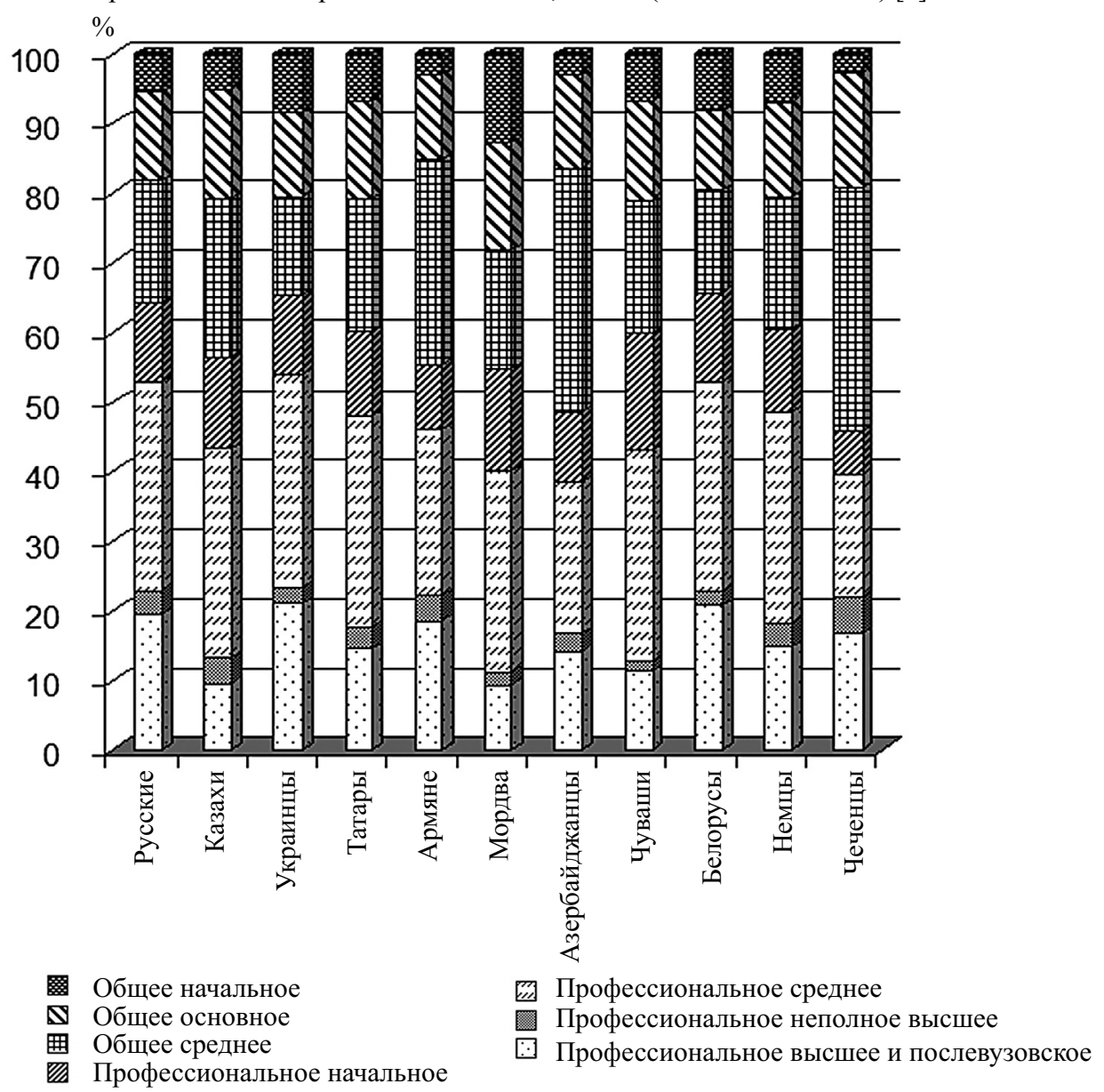

Рис.3. Уровень образования городского населения (этнический аспект) [3] 
старше трудоспособного возрастов (в дальнейшем II и III группы населения), соответственно 81,9 и 80,7\%, высок он и среди молодежи (16-29 лет) $79,1 \%$. У группы населения до трудоспособного возраста (далее I группа) у 41,8\% один источник средств существования (этот источник - иждивение, однако он у более чем 50\% детей дополняется различными пособиями). Женщины пенсионного возраста чаще мужчин указали два и более источника дохода. Это объясняется занятостью женщин в общественном производстве после выхода на пенсию или получением пособия.

Итак, можно выделить три главных источника средств к существованию у населения - в порядке убывания их распространенности: трудовая деятельность - иждивение - пенсия (кроме инвалидности). Следующие по важности два источника - «личное подсобное хозяйство» и «пособия» (кроме пособия по безработице). На личное подсобное хозяйство четвертый по значимости источник - указали 12,5 чел. из 100 жителей России, в Саратовской области этот показатель - 9,4; чуть меньше в Российской Федерации - 11,5 из 100 указали на пособия, в нашем регионе этот показатель 8,4. Этими пятью источниками дохода список значимых источников средств к существованию российского населения собственно исчерпывается. Идущие далее по ранжиру источники упоминаются гораздо реже. Совсем редко - «сбережения» и «доход от сдачи в наем или в аренду имущества» (1 из 700 чел. по Российской Федерации, 1 из 730 чел. в Саратовской области). По поводу последних, однако, утверждается, что они сильно недоучтены.

Остается еще группа источников, объединенная под рубрикой «иной источник» $(1,5 \%$ в Российской Федерации, 1,4\% в Саратовской области), что заметно выше значений для таких источников средств к существованию, как пособие по безработице и почти совпадает по распространенности с «другими видами государственного обеспечения».

По степени распространенности можно выделить следующую группу источников:

- пять наиважнейших: трудовая деятельность, иждивение, пенсии, личное подсобное хозяйство, пособия;

- четыре «второстепенных»: пенсия по инвалидности, стипендия, «другой вид государственного обеспечения», «иной источник»;

- три «редких»: пособие по безработице, сбережения, рента с имущества.

Перепись свидетельствует о значительных различиях в структуре источников средств к существованию городского и сельского населения. В России с одним источником средств к существованию живет только половина сельских жителей. В Саратовской области это 55,4\%, причем женщин больше, чем мужчин. Еще выше этот показатель у женщин III группы (70,6\%), что свидетельствует о том, что женщинам в пенсионном возрасте на селе труднее найти занятость. В I группе населения один источник средств существования только у $18 \%$ (иждивение, однако он у более чем $80 \%$ детей дополняется различными пособиями).

Кроме того, стоит отметить, что весьма значительная часть сельчан живут на пособия (встречаются более чем в 2 раза чаще, чем у горожан). Чаще упоминаются такие источники, как иждивение и пенсии, в том числе пенсии по инвалидности, и значительно реже - стипендии.

Соответственно разнятся доли населения с одним и несколькими источниками. Городской тип - жизнь с одним источником средств к существованию (более $80 \%$ ), а в селе нормой является жизнь и с одним (55,4\%), и с двумя (42,9\%) источниками. Таким образом, множественность источников средств к существованию - специфическая черта сельского уклада жизни. Эта черта порождает неоднородность сельского населения в отношении числа источников средств к существованию: одна половина имеет единственный доход, другая половина - несколько. Состав источников средств к существованию городского населения предельно прост - трудовая деятельность, иждивение и пенсия.

Источники средств к существованию населения области обнаруживают тесную связь с возрастом. Три главных источника средств к существованию, которые естественным образом сменяют друг друга при переходе от младших возрастов к старшим: иждивение - трудовая деятельность - пенсия (кроме пенсии по инвалидности). До 20 лет доминирует иждивение, после 20 и до возраста выхода на пенсию - трудовая деятельность, далее пенсия. Доля следующего по распространенности источника, личного подсобного хозяйства, увеличивается с возрастом, достигая максимума в 65-69 лет.

Пособия имеют четкую локализацию и по возрасту и по полу. В детском возрасте они являются вторым по значимости источником средств к существованию. В возрастах от 20 лет и старше их можно встретить только у женщин.

Стипендия, обычно как второй источник к существованию, также локализована по возрасту, более $90 \%$ ее получающих - молодые люди в возрасте 16-29 лет.

Довольно предсказуемую зависимость от возраста имеет число источников средств к существованию. В детском возрасте, когда нет самостоятельно заработанного дохода, число источников максимально (иждивение, пособие, стипендия и др.), появление самостоятельного дохода минимизирует это число. При приближении к пенсионному рубежу и вскоре после выхода на пенсию оно снова увеличивается, а затем снова снижается, по-видимому из-за уменьшения возможностей использования дополнительного источника. Распределение населения по возрасту и по числу источников средств к существованию показывает, что после достижения рабочего возраста большинство городского населения имеет единственный источник средств к существованию. Но 
в селе доля обладателей нескольких источников весьма значительна во всех возрастах, даже в интервале 20-49 лет она составляет 30-40\%.

Различия по числу и составу источников средств к существованию по большим городам хорошо иллюстрируют данные табл. 6. Есть существенные различия и по этнической принадлежности.

Таблица 6

Источники средств к существованию, 2002, \% ко всему населению* [5]

\begin{tabular}{|l|c|c|c|c|c|c|}
\hline \multicolumn{1}{|c|}{$\begin{array}{c}\text { Источники средств } \\
\text { к существованию }\end{array}$} & $\begin{array}{c}\text { Городское } \\
\text { население }\end{array}$ & $\begin{array}{c}\text { Сельское } \\
\text { население }\end{array}$ & Саратов & Балаково & Балашов & Энгельс \\
\hline Все население & 100,0 & 100,0 & 100,0 & 100,0 & 100,0 & 100,0 \\
\hline $\begin{array}{l}\text { Из них указавшие: } \\
\text { доход от трудовой деятель- } \\
\text { ности (кроме ЛПХ)/доход от } \\
\text { ЛПХ }\end{array}$ & $43,3 / 3,6$ & $32,5 / 30,5$ & $44,9 / 2,3$ & $47,4 / 4,4$ & $38,0 / 2,5$ & $43,9 / 1,3$ \\
\hline $\begin{array}{l}\text { пенсию(кроме пенсии по инва- } \\
\text { лидности) }\end{array}$ & 23,2 & 24,5 & 23,5 & 21,9 & 23,9 & 21,5 \\
\hline стипендию & 2,8 & 1,1 & 3,2 & 1,5 & 4,2 & 2,5 \\
\hline $\begin{array}{l}\text { пособие (кроме пособия по } \\
\text { безработице) }\end{array}$ & 9,1 & 19,9 & 6,3 & 7,1 & 10,6 & 6,5 \\
\hline на иждивении отдельных лиц & 29,0 & 31,5 & 28,3 & 28,8 & 31,4 & 29,9 \\
\hline $\begin{array}{l}\text { Из общей численности населе- } \\
\text { ния указавшие: } \\
\text { один источник }\end{array}$ & 81,6 & 55,4 & 83,7 & 83,5 & 80,9 & 86,6 \\
\hline два источника & 17,1 & 42,9 & 14,4 & 15,1 & 18,5 & 12,9 \\
\hline
\end{tabular}

* Рассматриваются основные источники средств к существованию и необходимые по теме данной работы.

В этническом измерении: значительная доля лиц, находящихся на иждивении, представлена у казахов, армян, азербайджанцев, чеченцев. Эти показатели хорошо соотносятся со значениями, характеризующими данные народы как многодетные и «молодые». Определенная часть женщин разных возрастов также находится на иждивении (рис. 4).

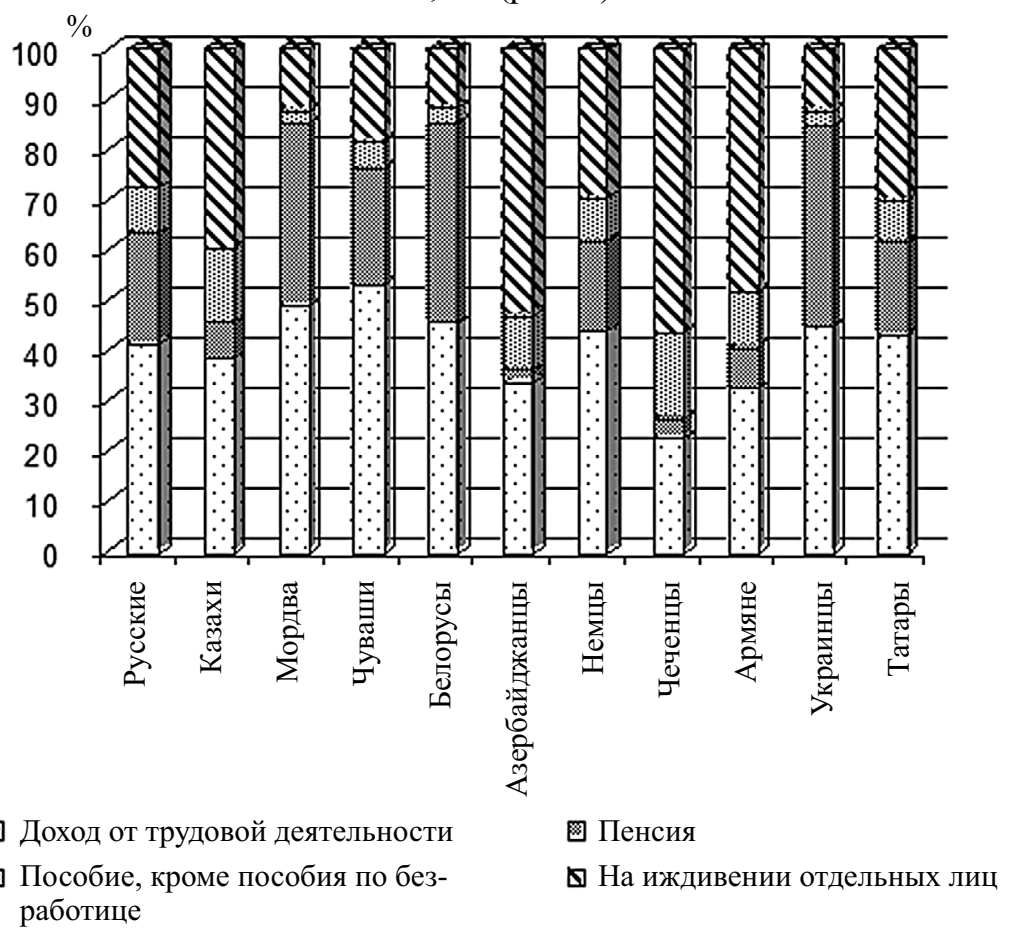

Рис. 4. Источники средств к существованию городского населения (этнический аспект) [3]

Характеристику населения по «экономической активности» и «положению в занятии» можно считать комплексной, отражающей возрастные особенности населения области, больших городов и этнической принадлежности, их ориентацию на получение образования, сложившиеся источники средств к существованию, менталитет (табл. 7). 
Доля населения, занятого в экономике в возрасте 15 лет и старше, и по положению в занятии, 2002, \% [6]

\begin{tabular}{|c|c|c|c|c|c|c|}
\hline \multirow{3}{*}{ Население } & \multirow{3}{*}{ Занятые } & \multicolumn{5}{|c|}{ Из всех занятых, в том числе по положению в занятии } \\
\hline & & \multirow{2}{*}{$\begin{array}{c}\text { работаю- } \\
\text { щие по } \\
\text { найму }\end{array}$} & \multirow{2}{*}{$\begin{array}{l}\text { работающие } \\
\text { не по найму }\end{array}$} & \multicolumn{3}{|c|}{ из них } \\
\hline & & & & $\begin{array}{c}\text { с привлечением } \\
\text { наемных работников }\end{array}$ & $\begin{array}{c}\text { без привлечения } \\
\text { наемных работников }\end{array}$ & иное \\
\hline Всего по области & 40,0 & 94,5 & 5,5 & 30,3 & 60,1 & 9,6 \\
\hline $\begin{array}{l}\text { В том числе: } \\
\text { г. Саратов } \\
\end{array}$ & 44,6 & 94,2 & 5,8 & 35,6 & 55,8 & 8,6 \\
\hline г.Балаково & 47,2 & 93,8 & 6,2 & 32,4 & 61,9 & 5,7 \\
\hline г. Балашов & 37,8 & 90,9 & 9,1 & 17,3 & 73,4 & 9,3 \\
\hline г. Энгельс & 43,6 & 94,8 & 5,2 & 30,1 & 62,2 & 7,7 \\
\hline
\end{tabular}

Среди собственников предприятий, людей занимающихся индивидуальной трудовой деятельностью чаще встречаются армяне, азербайджанцы, чеченцы. Среди этих же народов чаще всего можно встретить владельцев небольших предприятий, использующих наемных работников. Причину таких предпочтений отчасти можно соотнести со сложившимся еще ранее стереотипом «этнического разделения труда», также на современном этапе прослеживается взаимосвязь занятости с новыми экономическими реалиями в стране, временем прибытия на постоянное проживание в города Саратовской области, поддержкой диаспоры (рис. 5, 6).

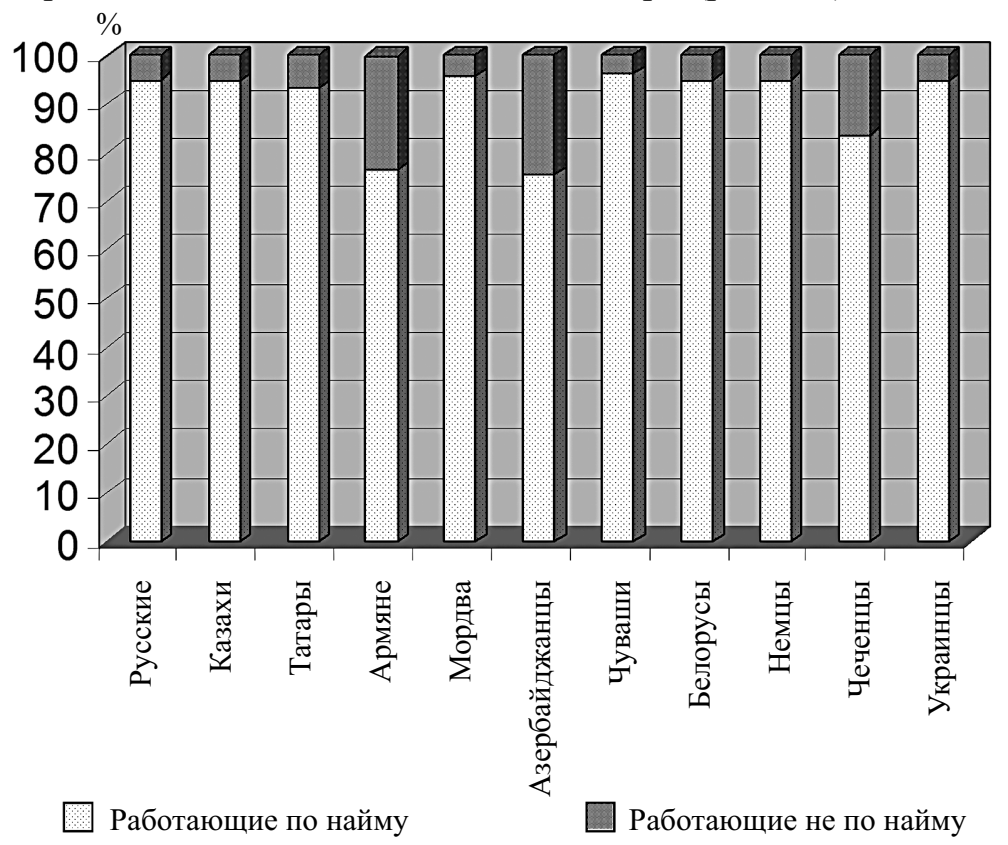

Рис. 5. Занятое население в экономике по положению в занятии [3]

Среди занятого городского населения также прослеживаются предпочтения по видам экономической деятельности у разных народов. Так, на предприятиях в обрабатывающих отраслях доля русских и украинцев выше других, в строительстве - заметная доля азербайджанцев, чеченцев, казахов. В «оптовой торговле, социальных и персональных услугах» большую долю среди занятых составляют татары, казахи, народы Кавказа. «Транспорт и связь»- одинаково привлекательны для всех. В разделе экономической деятельности - «государственное управление и обеспечение военной безопасности, обязательное социальное обеспечение» - доля занятых украинцев и русских выше. Такое же соотношение в «обра- зовании». Среди занятых в «здравоохранении и предоставлении социальных услуг» значительно представительство казахов, русских, украинцев, татар [7] .

Из проведенного анализа можно сделать следующие выводы. На демографическую и социально-экономическую структурные характеристики горожан различной этнической принадлежности (рассматриваемых в статье) оказывают влияние следующие процессы:

- процессы естественного воспроизводства (низкая рождаемость), ассимиляционные (мордва, чуваши, белорусы, украинцы, немцы);

- естественное (более высокая рождаемость) и механическое (положительное миграционное 


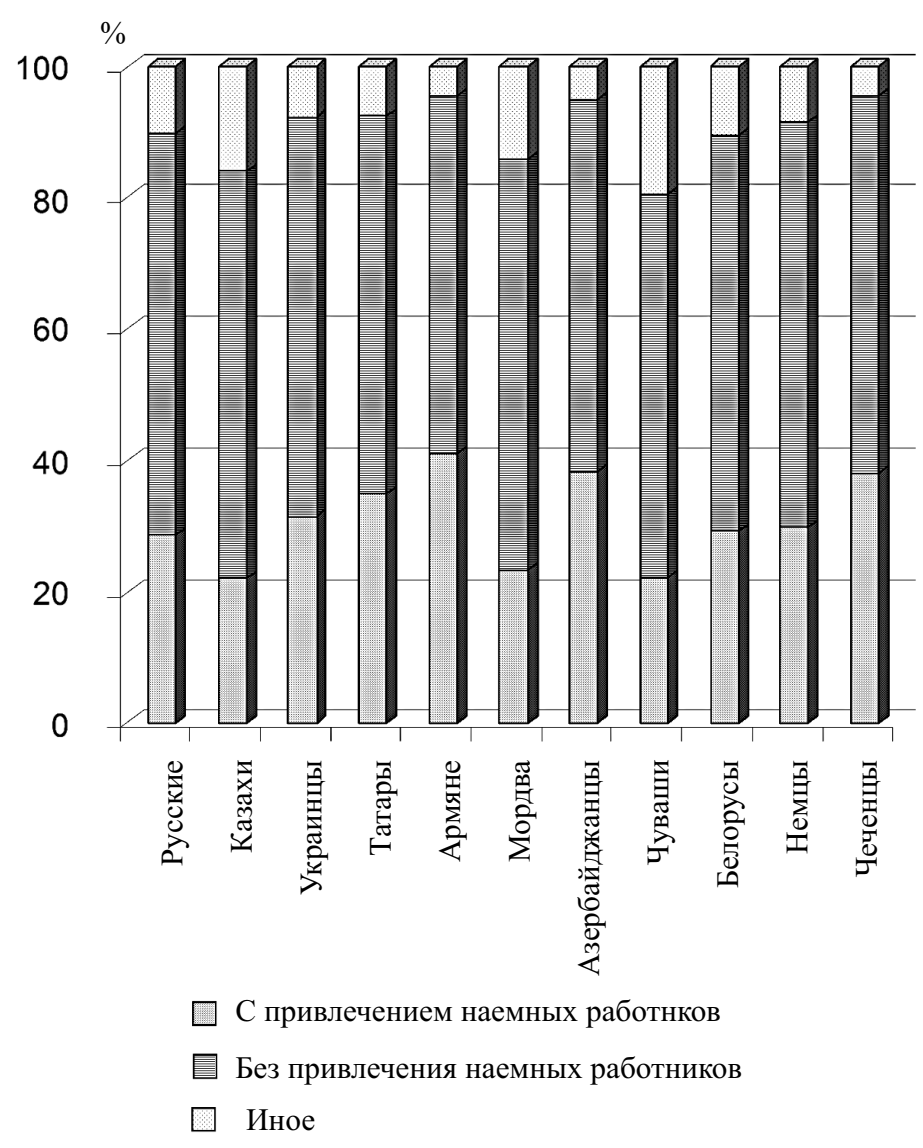

Рис. 6. Соотношение собственников по использованию рабочей силы [3]

сальдо) воспроизводство, процессы аккультурации (освоение новых культурных моделей, заимствованных в ходе контактов с другим сообществом) (армяне, азербайджанцы, чеченцы, казахи).

Данное исследование может быть использовано для составления демографических и экономических прогнозов развития области. Этнический аспект характеристики необходим для изучения взаимодействия этнических групп в образовательной и экономической сферах.

\section{Библиографический список}

1. Города и районы Саратовской области в 2002: Стат. сб. Саратов, 2003. $156 \mathrm{c}$.
2. Демографический ежегодник Саратовской области 2006 год: Стат. сб. Саратов, 2007. 186 с.

3. Национальный состав населения: Стат. сб. Саратов, 2005. $172 \mathrm{c}$.

4. Население России 2003-2004: Одиннадцатыйдвенадцатый ежегодный демографический доклад / Под ред. А.Г.Вишневского. М., 2006. 356 с.

5. Источники средств к существованию: Стат. сб. Саратов, 2004. $222 \mathrm{c}$.

6. Занятость населения: Стат. сб. Саратов, 2007. Ч. ІІ. $238 \mathrm{c}$.

7. Занятость населения: Стат. сб. Саратов, 2007. Ч. І. $206 \mathrm{c}$. 